\title{
Difficult to Heal Wounds Intralesional Insulin Therapy Trial
}

\author{
Neide Kalil Gaspar, Antonio Pedro de Andrade Gaspar \\ Departament of Dermatology, Universidade Federal Fluminense (UFF), Niterói (RJ), Brazil \\ Email address: \\ neide2605@yahoo.com.br (N. K. Gaspar)

\section{To cite this article:} \\ Neide Kalil Gaspar, Antonio Pedro de Andrade Gaspar. Difficult to Heal Wounds Intralesional Insulin Therapy Trial. Journal of Surgery. \\ Vol. 8, No. 6, 2020, pp. 184-189. doi: 10.11648/j.js.20200806.13
}

Received: January 14, 2020; Accepted: February 7, 2020; Published: November 9, 2020

\begin{abstract}
Introduction-Insulin exerts metabolic and growth-stimulating actions both through its own receptors and the receptors of its homologous factors (IGFs), although with different degrees of affinity. The A receptor of insulin acts more intensely on the cell membrane, with a metabolic response, whereas the B receptor is quickly internalized, stimulates cell growth, can be directed to the treatment of wounds difficult to heal. Objective-we proposes to evaluate the potential of insulin as an inducing agent in the regeneration of wounds that are difficult to heal as a therapeutic option. Methodology-Simultaneous intra and perilesional injections of $0.01 \mathrm{ml}$ of the solution containing 5UI of NPH single-component insulin diluted in $1 \mathrm{ml}$ of lidocaine into various planes and wound sites. Clinical, glycemic and photographic evaluations of the patients were performed. Results-The cicatricial response occured in all patients and observed since the first applications. Withouth glycemic changes. Comments - The responses obtained can be attributed to both the stimulation of insulin receptors and that of their counterparts. Conclusions-The method was effective and without adverse effects. Different intervals between applications did not change the results. The availability of insulin and safety for its use indicate the method as a therapeutic option in difficult to heal wounds.
\end{abstract}

Keywords: Wound Healing, Insulin, Growth Factor Wounds and Injuries, Difficult Wound Healing, Insulin Therapy, Growth Factors

\section{Introduction}

Although insulin-like growth factors (IGF-1 and IGF-2) were originally considered involved only in regulating cell growth, both insulin and IGFs are capable of modifying glucose uptake and cell growth through translocation of different receptors (IR, IGF1-1R and IGF2-2R) [1-4] that are expressed by all types of animal cells.

Insulin binds to its 1 Rs receptors with higher affinity than to IGF1-1R, whereas to IGFs 1 and 2 bind to their cognate receptors with greater affinity than insulin 1Rs. [3] These receptors are transmembrane glycoproteins, generated by alternative tissue splicings $[5,6]$ and mediate pleiotrophic actions in a myriad of biological functions.

The structural differences between insulin and IGFs, relate to their polypeptide chains. While IGFs contain the polypeptide chains $\mathrm{A}, \mathrm{B}, \mathrm{C}$ and $\mathrm{D}$, insulin contains only the $\mathrm{A}$ and $\mathrm{B}$ chains. The mitogenic activity of these receptors depends on their internalization while signaling to the metabolic activity occurs on the cell membrane. [7] The receptor A (IR-A) is quickly internalized in response to insulin than the B receptor (IR-B), thus stimulating gene transcription through mitogen activated protein kinase (MAPK).

Although all cell types express both forms of IRs at different levels, IR-A predominates in fetal tissue and cancer cells. IR-B predominates in adult differentiated tissues, regulating glucose homeostasis. [8]

The high expression of receptor A, which occurs in fetal cells, is common in cancer and indicates proliferative and anti-apoptotic response, prevailing over isoform B. Inactivation of B receptor favors IGF-1 and cell viability. [9]

Both endogenous and exogenous hyperinsulinemia promote the phosphorylation and activation of farnesyltransferase with increase in the plasma membrane of the RAS protein, [12] with information transmission to the nucleus and cellular multiplicative response, contributing to tumor development. [10-15]

The association of hyperinsulinemia with the tumor stimulus $[8,16,17,9,15,18]$ and with the stimulatory activity of IGF1 $[1,2,7,9,10]$ determining cell migration and proliferation, indicates its potential as a cicatricial inducer. 


\section{Use of Tissue Stimulatory Activity of Insulin}

The stimulatory potential of insulin has been used by us in humans to recover cutaneous and subcutaneous atrophies. [19] During the trials, the authors used insulin in 5UI applications diluted and fractionated in multiple simultaneous injections of $0.05 \mathrm{UI}$, locally and timely repeated in different planes and intervals, aiming at their local function. No changes in glycemic levels or any systemic modification related with the method were observed in these procedures. The method was further tested by us to accelerate the healing of experimental wounds in Wistar rats. [20] Recently, advantages have also been reported in the application of insulin ointment to second degree burns in diabetic rats. [21]

The mitogenic property of insulin has also been assayed for tissue protection in experimental models of rats with severe burns and myocardial injury, [22] hepatic injury [23, 24] and pulmonary injury. [25]

Combined administration of insulin and nerve growth factor (NGF), in a distinct manner from NGF alone, has been shown to promote increased angiogenesis by accelerating the healing of burns in diabetic rats.[26]

Hyperglycemia due to hypermetabolic response to stress is a common occurrence after thermal injury. Burned pediatric patients who presented damage from glucose tolerance, [27a] who underwent intense insulin therapy, improved mitochondrial function [28b] as well as protein synthesis. [27-29]

The results obtained by the different authors indicate the possibility of using insulin as a wound healing inducer.

\section{Difficult to Heal Wounds. Therapeutic Insulin Trial}

\subsection{Objective}

To evaluate the action of insulin in the regeneration of wounds that are difficult to heal.

\subsection{Methodology}

1. Intralesional and perilesional applications, of 4-5UI of $\mathrm{NPH}^{*}$ monocomponent insulin, diluted in $1 \mathrm{ml}$ of lidocaine in multiple simultaneous injections of $0.01 \mathrm{ml}$, in various planes and lesion points, repeated at variable time intervals, in 7 wounds with scarring difficulty. Debridement of wounds with necrotic tissues on the first day of treatment. Three patients (2, 5 and 7) had topical and daily addition of one drop of undiluted insulin to the wound surface.

In the purulent lesions, simultaneous application of topical antibiotics were done.

There was no selection of patients regarding the etiology of the wounds nor in relation to the age group. These were treated with varying intervals between applications.

* Novolin Nordisk Insulin NPH 100UI.

2. Glycemic evaluations were made after the first application.
3. Clinical and photographic documentation of patients was done.

\subsection{Patients}

1. A 29-year-old female patient for 127 days with an intergluteal surgical wound, $9 \mathrm{~cm}$ in diameter, reaching the entire skin thickness, due to cosmetic surgery for implantation of silicone prosthesis in the gluteal region with the aim of increasing local volume. Without any sign of reduction, the wound had not responded to treatment with hyperbaric oxygen and topical medications.

2. A 54-year-old male patient with 30 days of incandescent charcoal wound on the inner side of the right calf with $4 \mathrm{~cm}$ of diameter and $1 \mathrm{~cm}$ depth, with purulent borders and background, without cicatricial evolution.

3. A 21-year-old male patient had 136 days of necrotic background, $6 \mathrm{~cm}$ diameter, reaching adipose tissue with no healing signs and a probable "brown spider" sting (Loxosceles).

4. A 23-year-old male patient* (Figures 1-2), stung in the gluteal region by brown spider (Loxosceles)*. The treatment started after 60 days, without debridement of the lesion, presenting a large necrotic ulcer, with raised lips and necrotic background in the gluteal region.**

The venom of the brown spider is usually painless, but causes chronic, non-healing necrotic wound, characterized by tissue destruction by metalloproteinases ${ }^{30}$ that remains for several months without healing.

**Patient diagnosed and treated with this process, by the dermatologist Dr. Marília Nunes Nogueira.

5. A 29-year-old male patient (Figures 3-4), with extensive bilateral, painful axillary wounds reaching a large part of the subcutaneous tissue, with necrosis, exudation, and unbroken edges without any cicatricial tendencies, evolving for 15 days and resulting from subcutaneous surgical curettage of sweat glands.

6. A 81-year-old female patient, for 93 days with a traumatic wound in the middle-third of the right pretibial, drained 30 days before the hematoma exit and aspirated for seroma removal one week later. It was previously treated with antibiotics, anti-inflammatories and ointments, with no results. At the examination, purulent lesion, $10 / 1.5 \mathrm{~cm}$, reaching the subcutaneous tissue with detached borders without signs of regenerative activity.

7. A 94-year-old female patient (Figures 5-6), in an advanced stage of Alzheimer's disease, and for about 4 months with large pressure ulcer in the coccygeal region, showing bone surface and, under the borders, $4.5 \mathrm{~cm}$ dead space, covered by blackened necrotic tissue. Due to the physical conditions of the patient, the procedure was performed only aiming at its better tissue preservation.

8. Female patient of 76 years, with traumatic wound with no cicatricial tendency.

\subsection{Results}

Patient-specific data are listed in the Woundlessness chart. 
All wounds with necrosis were debrided on the first day of treatment, except for the wound in patient number 4 . The onset of cicatricial regenerative activity in all lesions was observed between 1 and 2 days after the first application.

There were no adverse effects or changes in glycemic levels during or after treatment.

The 94-year-old patient continued her treatment for two months, later dying of natural causes. Due to the extension of the lesion, together with the impossibility of surgical solution, as well as the possible unwanted unfolding inherent to the patient's age, it was evaluated that the treatment proposed here would be conducted with the best risk-benefit ratio.

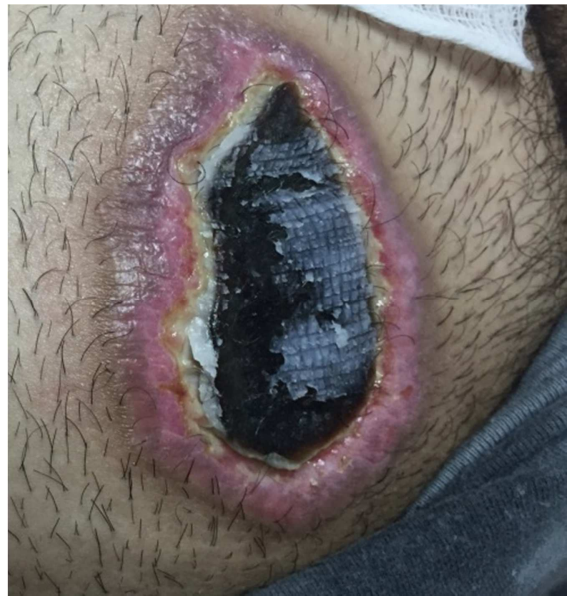

Figure 1. Patient 4- Pre-treatment, necrotic lesion, by brown spider bite.

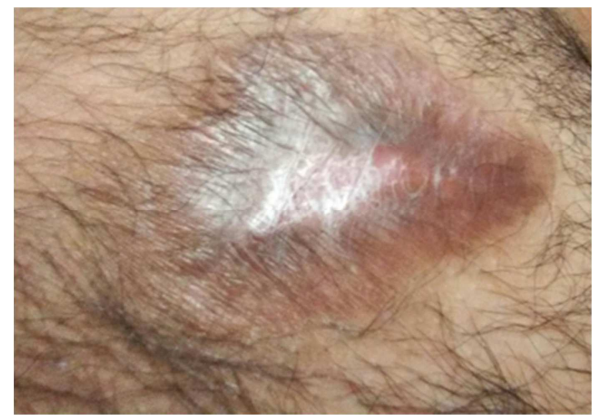

Figure 2. Patient 4- 15 applications. After 40 days. Complete healing.

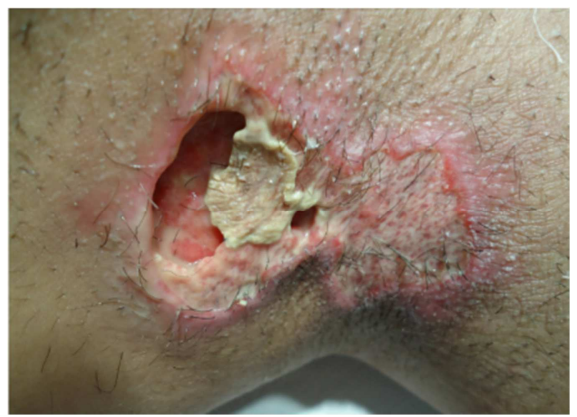

Figure 3. Patient 5- a large part of the subcutaneous tissue, with necrosis, exudation, and unbroken edges without any cicatricial tendencies. After 7 applications at 16 days of treatment. Partial healing.

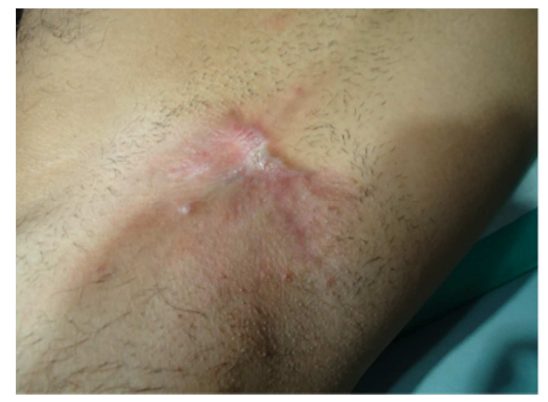

Figure 4. Patient 5- After 7 applications at 16 days of treatment. Partial healing.

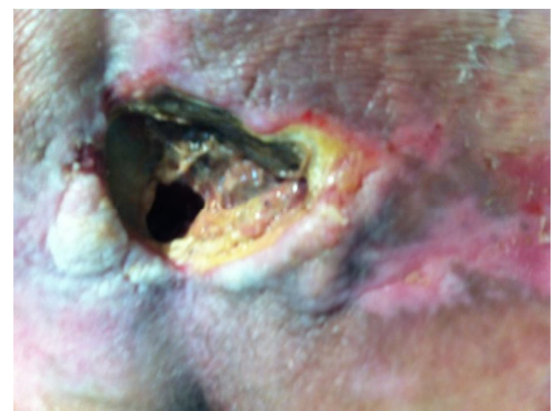

Figure 4. Patient 7- 4 months with large pressure ulcer in the coccygeal region, showing bone surface and, under the borders, $4.5 \mathrm{~cm}$ dead space, covered by blackened necrotic tissue.

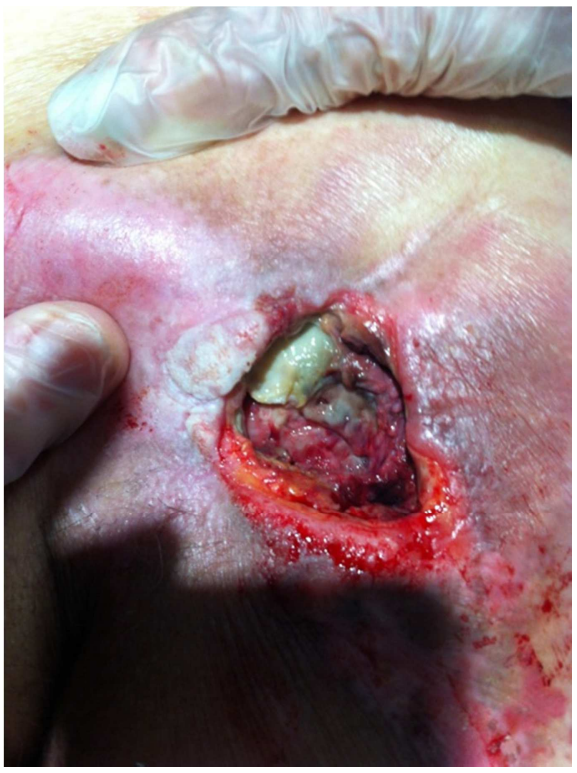

Figure 5. Patient 7-After 6 applications.

\section{Discussion}

Numerous investigations have been carried out with the purpose of enhancing the cicatricial process in wounds of different etiologies that do not respond to the treatments recommended by medical practice. Even in the procedures in which excellent results are demonstrated, they present difficulties for routine therapeutic use.

Cicatricial stimuli obtained by the insertion of different growth factors have been attested by different authors. [31-34] However, the factors employed are still not available in 
standardized and safe conditions for therapeutic use.

Another peculiarity of such factors to further restrict their use is in the fact that they determine stimuli that hold some cellular specificity distinct from insulin, which has receptors in all eukaryotic cells.

The application of platelet-rich plasma, [35] requires equipment, professionals with specific technical training, as well as a microbiologically acceptable environment: a rarely available combination of requirements.

The use of multipotent bone marrow cells [36] or the abdominal adipose tissue stroma $[37,38]$ is capable of promoting the recovery of extensive tissue lesions. However, it is an expensive and demanding procedure of laboratory and technical equipment, being restricted to exceptional situations and still executed in experimental procedures.

Although a double-blind or large-sample trial was not performed, it was found that, compared with the time of previous evolution of the treated wounds, with the time elapsed for healing through the treatment tested, the results achieved and the extreme ease of execution demonstrate the method suitability for routine therapeutic use. This conclusion is corroborated by the responses obtained with the use of insulin in animal tests, [23-26] in human atrophies [19, $20]$ as well as in the cicatricial recovery of burned pediatric patients. [26, 28]

\section{Comments}

The obtained responses can be attributed to the stimulation of both the insulin receptors and their homologues IGF1 and IGF2. The fractioning of the doses in simultaneous multiple injections aimed to benefit the local insulin activity and the reduction of its systemic absorption.

The healing process requires greater and orderly production of chemotactic and growth factors, capable of increasing the presence of the cell types specifically required for the cicatricial stage. Determining which predominant factors involved in each biological moment of a cicatricial process and applying them safely is a considerable challenge. The choice of insulin, due to its physiological potential in all the cellular vital phases, is a therapeutic to be considered.

The intralesional use of insulin ensures its absorption, greater stability, longer activity period and absence of contact with necrotic or enzymatic materials capable of preventing or change its activity in topical use.

\section{Conclusions}

1. Insulin therapy has been shown to be effective and without adverse effects;

2. Different intervals between applications did not change the obtained results;

3. The availability of insulin and the safety of its use indicate the authors' method as an advantageous therapeutic option in the recovery of tissues;

4. The availability, low cost and wide knowledge available on this substance justify its indication as a therapeutic method for are difficult to heal wounds.

Table 1. Wounds without a tendency to heal.

\begin{tabular}{|c|c|c|c|c|c|c|c|}
\hline \multicolumn{8}{|c|}{ Wounds without a tendency to heal } \\
\hline Patient & Sex & Age & Etiology & Evolution & Inicial response & Number of applications & Resolution (in days) \\
\hline 1 & Fem & 29 & Cirurgic & 127 days & $48 \mathrm{~h}$ & 11 & 21 \\
\hline 2 & Masc & 54 & Incandescent coal burning & 30 days & $72 \mathrm{~h}$ & 4 & 15 \\
\hline 3 & Masc & 21 & Probable brown spider bite & 136 days & $48 \mathrm{~h}$ & 15 & 35 \\
\hline 4 & Masc & 23 & Brown spider bite & 60 days & $48 \mathrm{~h}$ & 15 & 40 \\
\hline 5 & Masc & 29 & Cirurgic & 16 days & $24 \mathrm{~h}$ & 7 & 21 \\
\hline 6 & Fem & 81 & Traumatic & 93 days & $48 \mathrm{~h}$ & 8 & 36 \\
\hline 7 & Fem & 93 & Pressure ulcer & 120 dias & $24 \mathrm{~h}$ & 6 & $*$ \\
\hline 8 & Fem & 76 & Traumatic wound & 12 dias & $48 \mathrm{~h}$ & 5 & 12 \\
\hline
\end{tabular}

[4] Slaaby R, Schäffer L, Lautrup-Larsen I, Andersen AS, Shaw AC, Mathiasen IS et al. Hybrid receptors formed by insulin receptor (IR) and insulin-like growth factor I receptor (IGF-IR) have low insulin and high IGF-1 affinity irrespective of the IR splice variant. J Biol Chem. 2006 Sep 8; 281 (36): 25869-74.

[1] Czeck MP, Oppenheimer CL, Massagué J. Interrelationhip among receptor structures for insulin and peptide growth factors. Fed Proc. 1983; 42: 2598-602.

[2] Ish-Shalon D, Christoffersen CT, Vorwek P, Sacerdoti-Sierra N, Naor D, De Metys P. Mitogenic properties of insulin and insulin analogues mediated by the insulin receptor. Diabetologia. 1997; 40: S25-S31.

[3] Pandini G, Frasca F, Mineo R, Sciacca L, Vigneri R, Belfiore A. Insulin/insulin-like growth factor I hybrid receptors have different biological characteristics depending on the insulin receptor isoform involved. J. Biol. Chem. 2002; 277: 3968439695.

[5] Mosthaf L, Grako K, Dull TJ, Coussens L, Ullrich A, and McClain DA. Functionally distinct insulin receptors generated by tissue-specific alternative splicing. EMBO. 1990; 9: 24092413.

[6] Brzozowski AM, Dodson EJ, Dodson GG, Murshudov GN, Verma C, Turkenburg JP et al. Structural origins of the functional divergence of human insulin-like growth factor-I and insulin. Biochemistry. 2002 Jul 30; 41 (30): 9389-97.

[7] Leitner JW, Kline T, Carel K, Goalstone M, Draznin B. Hyperinsulinemia potentiates activation of p21RAS by growth factors. Endocrinology. 1997; 138: 2211-4. 
[8] Pandinil G, Vigneri R, Costantino A, Frasca F, Ippolito A, Fujita-Yamaguchi $\mathrm{Y}$ et al. Insulin and insulin-like growth factor-I (IGF-I) receptor overexpression in breast cancers leads to insulin/IGF-I hybrid receptor overexpression: evidence for a second mechanism of IGF-I signaling. Clin. Cancer Res. 1999; 5: 1935-1944.

[9] Briekley GV, Macaulay SL, Forbes BE, Wallace JC, Cosgrove LJ, Macaulay VM. Silencing of the insulin receptor isoform A favors formation of type 1 insulin-like growth factor receptor (IGF-IR) homodimers and enhances ligand-induced IGF-IR activation and viability of human colon carcinoma cells. Endocrinology. 2010; 15: 1418-27.

[10] Gauguin L, Klaproth B, Sajid W, Andersen AS, McNeil KA, Forbes BE et al. Structural basis for the lower affinity of the insulin-like growth factors for the insulin receptor. J Biol Chem. 2008 Feb 1; 283 (5): 2604-13.

[11] Goalstone M, Carel K, Leitner JW, Draznin B. Insulin stimulates the phosphorylation and activity of farnesyltransferase via the Ras-mitogen-activated protein kinase pathway. Endocrinology. 1997; 138: 5119-24.

[12] Goalstone ML, Wall K, Leitner JW, Kurowski T, Ruderman N, Pan SJ et al. Increased amounts of farnesylated p21Ras in tissues of hyperinsulinaemic animals. Diabetologia. 1999; 42: 310-6.

[13] Draznin B, Miles P, Kruszninska Y, Olefsky J, Friedman J, Golovchenko I et al. Effects of insulin on prenylation as a mechanism of potentially detrimental influence of hyperinsulinemia. Endocrinology. 2000; 141: 1310-6.

[14] Draznin B. Mechanism of the mitogenic influence of hyperinsulinemia. Diabetol Metabol Syndr. 2011; 3-10.

[15] Mazur, Masur K, Vetter C, Hinz A, Tomas H, Niggemann B et al. Dibetogenic glucose and insulin concentrations modulate transcriptome and protein levels involved in tumour cell migration, adhesion and proliferation. Br J Cancer. 2011; 104: 345-52.

[16] Vella V, Pandini G, Sciacca L, Mineo R, Vigneri R, Pezzino V et al. A novel autocrine loop involving IGF-II and the insulin receptor isoform-A stimulates growth of thyroid cancer. J Clin Endocrinol Metab. 2002; 87: 245-54.

[17] Saydah, Saydah SH, Platz EA, Rifai N, Popllak MN, Brancati FL. Association of markers of insulin and glucose control with subsequent colorectal cancer risk. Am J Epidemiol. 2003; 157: 1092-100

[18] Nead KT, Sharp SJ, Thompson DJ, Painter JN, Savage DB, Semple RK et al. Evidence of a Causal Association Between Insulinemia and Endometrial Cancer: A Mendelian Randomization Analysis. J Natl Cancer Inst. 2015; 107 (9) pii: djv178.

[19] Gaspar NK, Gaspar APA, Bruno AFM, Travassos Neto P. Tratamento das lipoatrofias localizadas com insulina monocomponente. An B Dermatol. 1984; 59: 135-136.

[20] Gaspar NK. Tese: Concurso Prof Titular: A importância da insulina nos processos regenerativos cutâneos e subcutâneos. Universidade Federal Fluminense 1995. RJ Brasil.

[21] Azevedo F, Pessoa A, Moreira G, Santos MD, Liberti E, Araujo E et al. Insulin on second-degree burns in diabetic rats. Biol Res Nurs. 2016; 18: 181-9.
[22] Lv GF, Chen B, Zhang WF, Wang YC, Cai WX, Tang CW et $a l$. The protective effect of intensive insulin treatment on the myocardium in severely scalded rats. Zhonghua Shao Shang Za Zhi. 2007; 23: 168-71.

[23] Wang YC, Jia CY, Zhang WF, Lv GF, Dong ML, Tang CW et al. Protective effect of insulin on oxygen-radical induced hepatic injury in severely scalded rats. Zhonghua Shao Shang Za Zhi. 2007; 23: 428-31.

[24] Jeschke MG, Kraft R, Song J, Gauglitz GG, Cox RA, Brooks $\mathrm{NC}$ et al. Insulin protects against hepatic damage postburn. Mol Med. 2011; 17: 516-22.

[25] Zhang WF, Zhu XX, Hu DH, Xu CF, Wang YC, LY GF, Intensive insulin treatment attenuates burn-initiated acute lung injury in rats: role of the protective endothelium. J Burn Care Res. 2011; 32: e51-8.

[26] Zhang J, Xue X, Xie P, Chang F. Effects of nerve growth factor mixed insulin on angiogenesis of burn wounds and expressions of bcl-2 and Bax in diabetic rats. Zhongguo Xiu Fu Chong Jian Wai Ke Za Zhi. 2011; 25: 354-60.

[27] Fram RY, Cree MG, Wolfe RR, Barr D, Herndon DN. Impaired tolerance in pediatric burn patients at discharge from the acute hospital stay. J Burn Care Res. 2010; 31 (5): 72833.

[28] Fram RY, Cree MG, Wolfe RR, Mlcak RP, Qian T, Chinkes $\mathrm{DL}$ et al. Intensive insulin therapy improves insulin sensitiivity and mitochondrial function in severely burned children. Crit Care Med. 2010; 38: 1496-83.

[29] Tuvdendorj D, Zhang XJ, Chinkes DL, Aarsland A, Kulp GA, Jeschke MG et al. Intensive insulin treatment increases donor site wound protein synthesis in burn patients. Surgery. 2011; 149: 512-8.

[30] Corrêa MA, Okamoto CK, Gonçalves-de-Andrade RM, van den Berg CW, Tambourgi DV. Sphingomyelinase D from Loxosceles laeta Venom Induces the Expression of MMP7 in Human Keratinocytes: Contribution to Dermonecrosis. PLoS One. 2016; 11: e0153090.

[31] Yan D1, Liu S, Zhao X, Bian $\mathrm{H}$, Yao X, Xing J et al. Recombinant human granulocyte macrophage colony stimulating factor in deep second-degree burn wound healing kell. Medicine (Baltimore). 2017 Jun; 96: e6881.

[32] Jasper J1, Roithmann S2, Camilotti RS3, Salum FG4, Cherubini K5, Zancanaro de Figueiredo MA5. Effect of GCSF on oral mucositis and traumatic ulcers produced in the tongue of rats undergoing radiotherapy: clinical and histologic evaluation. Oral Surg Oral Med Oral Pathol Oral Radiol. 2016; 122: $587-596$

[33] Ma C, Hernandez MA, Kirkpatrick VE, Liang LJ, Nouvong AL, Gordon II. Topical platelet-derived growth factor vs placebo therapy of diabetic foot ulcers offloaded with windowed casts: a randomized, controlled trial. Wounds. 2015; 27: 83-91.

[34] Smith OJ, Kanapathy M, Khajuria A, Prokopenko M, Hachach-Haram N, Mann H et al. Systematic review of the efficacy of fat grafting and platelet-rich plasma for wound healing. Int Wound J. 2018; 1-8. doi: 10.1111/iwj.12892.

[35] Abo-Elkheir W, Hamza F, Elmofty AM, Emam A, AbdlMoktader M, Elsherefy S et al. Role of cord blood and bone marrow mesenchymal stem cells in recent deep burn: a casecontrol prospective study. Am J Stem Cells. 2017; 6: 23-35. 
[36] Zou JP, Huang S, Peng Y, Liu HW, Cheng B, Fu XB et al. Mesenchymal stem cells/multipotent mesenchymal stromal cells (MSCs): potential role in healing cutaneous chronic wounds. Int J Low Extrem Wounds. 2012; 11: 244-53.

[37] Hyldig K, Riis S, Pennisi CP, Zachar V, Fink T. Implications of Extracellular Matrix Production by Adipose Tissue-Derived
Stem Cells for Development of Wound Healing Therapies. Int J Mol Sci. 2017; 31; 18: pii: E1167.

[38] Martinez-Zapata MJ, Martí-Carvajal AJ, Solà I, Expósito JA, Bolíbar I, Rodríguez L et al. Autologous platelet-rich plasma for treating chronic wounds. Cochrane Database Syst Rev. 2016; 25: CD006899. 